\title{
A Study of Flipped Classroom's Influence on Classroom Environment of College English Reading, Writing and Translating
}

\author{
Xian Xie and Qinghua Fang \\ Wuhan University of Science and Technology, Wuhan, Hubei, China \\ 408226875@qq.com, 312852383@qq.com
}

\begin{abstract}
Keywords: Flipped classroom; College English Reading; Writing and translating; Classroom environment; Individual differences
\end{abstract}

\begin{abstract}
This study used quantitative and qualitative methods to explore the characteristics of flipped classroom's influence on classroom environment of College English Reading, Writing and Translating, so as to summarize and reflect on the teaching characteristics of College English Reading, Writing and Translating. The results of the study indicates that after the flipped classroom teaching mode has been applied to Reading, Writing and Translating, students' performance and the classroom environment have been improved to some extent; students of the flipped classroom are generally satisfied with the flipped classroom environment; students show a certain degree of individual differences to the degree of cooperation, participation, self responsibility, task orientation and the teacher leadership and innovation. The study indicates that the implementation of flipped classroom teaching mode can optimize College English Reading, Writing and Translating classroom environment and realize the teaching target-the learner as the center in foreign language teaching and learning, but bring a greater challenge to teachers.
\end{abstract}

\section{Research Background}

Cai Jigang fully demonstrates China's College English teaching goal should be to cultivate students with strong reading, writing and translation ability in the Research of China's College English Teaching Objectives Set-Discussion Again on the Relations of Listening and Speaking and Reading and Writing. [1] Classroom is the main place for Chinese students to learn a foreign language, but since College English implementing graded class teaching model, class hour of Reading and Writing has been reduced leading increasing the difficulty of achieving the goal. Then, the empirical study of Yu Shulin also shows in Exploratory Study on College Foreign Language Classroom Environment that under the traditional teaching pattern in College English Reading, Writing and Translating class, interaction between teachers and students is greatly reduced, the teacher's personality and creative space are limited, positive role of teachers and students in the classroom environment are difficult to play, the classroom environment of Reading, Writing and Translating is inferior to that of Audio-visual [2]. Existing college language teaching research on teaching environmental factors, especially the classroom environment research is very few; the relevant empirical research is even scarce [3]. In this situation, it is necessary to study the classroom environment of Reading, Writing and Translating class in order to improve the teaching quality.

Classroom environment refers to the students' or teacher's perception or feelings to own class or classroom, which is the latent factor that decides the students' development [4]. It includes important potential factors that decide the study effects and affect students' cognitive and emotional development. Scholars abroad do not pay much attention to the definitions of it, but mainly focus on its structural analysis and measurement. Studies involve classroom environment theory construction, formulation and revision for measurement tools, factors affect the classroom environment and the relationship between classroom environment and learning achievement[2], while domestic research is mainly theory introduction and literature review [5,6]. From the research methods point of view, it is mainly quantitative study of the data collection through the classroom environment assessment inventory. From the perspective of research contents, classroom environment research has mainly focused on primary and secondary school mathematics, chemistry, 
physics and other natural science, fortunately, research of language classroom and higher education classroom gradually have began increasing in recent years, so far, domestic foreign language teaching researchers such as Sun Yunmei [7], Gaozhao [8], Liu Liyan [9] ,Yu Shulin [2], Zhao Qinghong [3], Ren Qingmei [10], Han Dawei [11]and Li Guangfeng [12] and so on have probed into study English classroom environment, they mainly invest teachers and students' perception situation of the classroom environment, measurement scale and influence of classroom environment for learning, which mark the beginning of the classroom environment research turning to discuss on teaching structure elements and teaching process elements. The classroom environment itself is a complex concept; the research on classroom environment characteristics provides the unique perspective of evaluation and reflection on the curriculum system and teaching mode to educators, thereby helping to improve the classroom environment and teaching effect [13].

Combined with the characteristics of local foreign language classroom, the paper adopts Fan Chunlin's point of view, the classroom environment refers to the social psychological environment of classroom, is aggregate of teacher-student interaction and student-student interaction in the basic elements and conditions, and classroom participants' personality, mental state and the psychological atmosphere of the classroom. The paper proposes from the aspects of classroom social environment and psychological environment to define classroom environment, with reference to Sun Yunmei's study of sociopsychological environment in the foreign language classroom[14] from Student's Collaboration, Student's Cooperation, Teacher's Support, Teacher's Leading, Classroom Involvement, Student's Responsibility, Task Orientation, Equality, Teacher's Innovation; at the same time, combined with Fan Chunlin's (2005) classification of the psychological environment, from the aspect of Personality Characteristics, Psychological State, Classroom Psychological Atmosphere, subdividing classroom environment into 12 factors. The study takes a specific College English Reading, Writing and Translating class as the case study, through the quantitative and qualitative methods to study the classroom environment of Reading, Writing and Translating class under flipped classroom teaching mode.

\section{Flipped Classroom and Flipped Reading, Writing and Translating Classroom}

Characteristics of Flipped Classroom. Flipped classroom originated in Forest Park High school of Colorado Rocky Mountain. in order to help students who often could not go to school on time, Chemistry teacher Jonathan Bermann and Aaron Sams recorded curriculum contents as PowerPoint, audio and video and then uploaded to the Internet for students to learn. [15] Flipped classroom subverts the traditional teaching form: "transmit knowledge in classroom + integrate knowledge after class", which applies online-learning leading students to make self learning pace according to individual learning situation, completing the knowledge impartment through finishing teachers' tasks before class and in the classroom through interactive asking and answering, the teacher designs targeted activities to check the internalization degree and help students to complete the knowledge internalization and absorbing. The time of this teaching mode is valuable, the leading role of teachers is weakened but the students' principal role is highlighted. [16] The key points of success flipped classroom are: teaching video, classroom activities and learning environment, which requires the designers of them, the teachers more, especially teachers' leadership and innovation. Meanwhile, the students combine virtual learning environment and actual learning environment to build a personalized collaborative learning in a relaxed and pleasant classroom environment to complete the knowledge construction [17]. Hence, students can focus more independent learning and cooperative learning; their opportunities to participate in classroom are increased. They become more free and equal to collaborate with other students to finish learning tasks and truly become the masters of learning. Subsequently, Lu Haiyan analyzed the feasibility of flipped classroom teaching mode in foreign language classroom and concluded its characteristics. Flipped classroom mode makes the role of teachers and students both change; teachers' teaching time is reduced in class, leaving the students more time for learning activities, so increasing the interaction [18]. He Zhaoyang pointed out that students in the flipped classroom were more likely to participate in class activities than in the traditional class. [19] The changes flipped classroom teaching mode brings 
have covered many aspects of classroom environment, so we think that the influences of College English Reading, Writing and Translating classroom environment that flipped classroom exert are of certain significance.

Flipped Reading, Writing and Translating Classroom Based on the characteristics of College English Reading, Writing and Translating, the application of flipped classroom will be different from other courses. During the preparation stage, the network interactive platform is established, including the teaching forum, the chatting group, the network community and so on to facilitate the interaction between the teacher and the students. Before class, the teacher will subdivide teaching contents into a plurality of knowledge chunks, record the important and difficult points as micro video, the length of which is generally $5 \sim 10$ minutes, the contents of which mainly includes the key vocabularies and grammars, added with the texts form such as words and sentence practices for students to practice in the form of Word, PowerPoint and so on. Before class, the teacher prepares them for students to learn and study, the students can freely choose to complete the task independently or in cooperation. They also can ask the teacher or their classmates for help online or in reality. In class, the teacher checks whether the contents have been grasped and completed ahead of schedule through asking and answering of language points, then, designs words blank-filling, rewriting, prompt translation activities for the students to consolidate key vocabularies and grammars, asks the students to explain the answer, designs related writing for students to practice, encourages the students writing more than one drafts, let the students criticize articles for each other and organizes group discussions on doubts and problems in writing. For last class of each unit, it is time for the real material translation practice which is associated with the theme of the unit. Before class, the teacher assigns the translation task through the network, together with the students selects model translation for students to review, appreciate and discuss translation skills and strategies. Before the end of each unit, the teacher leads students to summarize the difficulties of this unit in class. After class, the students can freely assess the effectiveness of learning in the network platform. And the students can freely speak in the seminar in the middle term.

\section{Research Methodologies}

Research Questions. This study mainly discusses the following questions:

1. Whether the classroom environment of College English Reading, Writing and Translating under the flipped classroom mode has been improved?

2. Are there any perception differences of students at different proficiency levels for the flipped classroom model?

Research Subjects. This study involved a case study of a non-English majors College English Reading, Writing and Translating class in Grade 2014 in Wuhan University of Science and Technology. Through the observation of the second semester, it was found that several problems such as limited class time, low classroom efficiency, few students interaction and cooperation existing in English Reading, Writing and Translating class, so we decided to apply flipped classroom teaching mode in the third semester. 31 students participated in this study, and 31 questionnaires were taken back.

Research Procedures. At the beginning of the third semester, the questionnaire was conducted to give a pre-test to measure the classroom environment to get the grades data and the classroom environment perception data. And then the same teacher applied flipped classroom teaching mode teaching a semester, during the period, gave the students a certain amount of interviews and with the same questionnaire gave a post-test at the end of the semester to get the grades data and the classroom environment perception data.

Questionnaire. Based on Fraser and Treagust's College and University Classroom Environment Inventory (CUCEI) and Sun Yunmei's College Comprehensive English Classroom Environment Inventory (CCECEI) questionnaires (CCECEI), combined the characteristics of Chinese language teaching, we made College English Reading, Writing and Translating Classroom Environment Inventory (CERWTCEI). In view of the influences of flipped classroom on the course, the author absorbed some advice of some experienced teachers, who put forward some valuable suggestions to 
improve the quality of questionnaire inventory. The questions used in the inventory mostly referenced from the College Comprehensive English Classroom Environment Inventory (CCECEI), so the reliability and validity could be guaranteed.

The questionnaire consists of two main parts. The first part is about the basic information of students; the second part contains 88 questions, which are divided into 12 main factors that represent the classroom environment. Among them, Student's Collaboration, Student's Cooperation, Teacher's Support, Teacher's Leading, Classroom Involvement, Student's Responsibility, Task Orientation, Equality, Teacher's Innovation are classroom social environment, and Personality Characteristics, Psychological State, Classroom Psychological Atmosphere belong to classroom psychological environment. The questionnaire applies Likert scale; each problem has five options, from "never" to "always" applying five-point grade approach.

Interview Questionnaires. In the process of flipped classroom teaching mode, the assistant teacher gives some interviews to students of different levels and records them. The interviews are mainly to make clear the students' true feelings of the flipped classroom teaching mode. The interview questions are as follows:

1. What do you think are the changes in class between this term and last term?

2. What do you acquire in class this semester?

3. Do you adapt to this kind of classroom atmosphere?

4. Have your English learning habits changed?

5. Do you want the teacher to continue with this teaching mode?

Data Analysis. The collected data was dealt with descriptive statistical analysis firstly, then by paired samples t-test to compare pre-test and post-test data of the whole class, so did the data of low score students, to analyze the whole class differences and the individual differences on environment perception; by using the independent sample t-test to analyze the classroom environment perception differences between students of high grades and low grades; at last, transcribing and analyzing the interview data. All statistical analyses use software SPSS20.0.

\section{Results and Analyses}

First of all, the test grades of whole class are dealt by paired samples t-test, getting the following Table 1 and Table 2,

Table 1 Paired samples t-test of grades

\begin{tabular}{|ll|r|r|r|r|}
\hline & \multicolumn{1}{|c|}{ Mean } & \multicolumn{1}{c|}{ N } & Std. Deviation & \multicolumn{1}{c|}{ Mean Std. Error } \\
\hline Pair 1 & Grades before & 3.26 & 31 & .893 & .160 \\
& Grades after & 3.32 & 31 & .791 & .142 \\
\hline
\end{tabular}

Table 1 shows that the overall performance of the class is improved by one semester, and the grades are more stable than before. The reason lies in the flexible assessment of flipped classroom teaching mode. Under the flipped classroom, the students' performance is evaluated not only by the final exam, but also by both considering the usual classroom performance and the performance of the mid-term seminar.

Table 2 Paired samples t-test of grades before and after

\begin{tabular}{|c|c|c|c|c|c|c|c|c|}
\hline & \multicolumn{5}{|c|}{ Paired Samples t-test } & \multirow[b]{3}{*}{$\mathrm{t}$} & \multirow[b]{3}{*}{$\mathrm{d}$} & \multirow[b]{3}{*}{ Sig. (2-tailed) } \\
\hline & \multirow[b]{2}{*}{ Mean } & \multirow{2}{*}{$\begin{array}{c}\text { Std. } \\
\text { Devi-at } \\
\text { ion }\end{array}$} & \multirow{2}{*}{$\begin{array}{c}\text { Mean } \\
\text { Std. } \\
\text { Error }\end{array}$} & \multicolumn{2}{|c|}{$\begin{array}{l}\text { 95\% Confidence interval of the } \\
\text { Difference }\end{array}$} & & & \\
\hline & & & & Lower Limited & Upper Limited & & & \\
\hline $\begin{array}{l}\text { Grades before-Grades } \\
\text { after }\end{array}$ & -.065 & .574 & .103 & -.275 & .146 & -.626 & 30 & .536 \\
\hline
\end{tabular}


Table 2 shows that although the students' grades have improved (mean $=-0.065$ ), but do not significantly improve $(\mathrm{t}=-0.626, \mathrm{df}=30, \mathrm{P}>0.05)$. The reason is that the experiment time is only one semester. We believe that after longer flipped classroom teaching, the student's performance will be greatly improved. And we also find that the classroom environment is of more vitality than before, so studying the classroom environment of flipped classroom is necessary.

Classroom Environment Comparing between Non -flipped Classroom (NFC) and Flipped Classroom (FC) Mode. Take the pre-test data and post-test to do paired samples t-test, in order to facilitate to record the statistics, the pre-test factor is "Student's Collaboration" and the post-test is "Student's Collaboration 1", the same as the below factors, getting the following Table 3,

Table 3 Paired samples t-test between NFC and FC

\begin{tabular}{|c|c|c|c|c|c|c|c|c|c|}
\hline & & \multicolumn{5}{|c|}{ Paired Samples t-test } & \multirow[b]{3}{*}{$\mathrm{t}$} & \multirow[b]{3}{*}{ df } & \multirow[b]{3}{*}{$\begin{array}{l}\text { Sig. }(2 \\
\text {-taile } \\
\text { d) }\end{array}$} \\
\hline & & \multirow[b]{2}{*}{ Mean } & \multirow[b]{2}{*}{$\begin{array}{l}\text { Std. } \\
\text { Deviati } \\
\text { on }\end{array}$} & \multirow[b]{2}{*}{$\begin{array}{l}\text { Mean } \\
\text { Std. } \\
\text { Error }\end{array}$} & \multicolumn{2}{|c|}{$\begin{array}{l}95 \% \text { Confidence } \\
\text { interval of the } \\
\text { Difference }\end{array}$} & & & \\
\hline & & & & & $\begin{array}{l}\text { Lower } \\
\text { Limited }\end{array}$ & $\begin{array}{l}\text { Upper } \\
\text { Limite } \\
\text { d }\end{array}$ & & & \\
\hline $\begin{array}{l}\text { Pair } \\
1\end{array}$ & $\begin{array}{l}\text { Grades before-Grades } \\
\text { after }\end{array}$ & -.065 & .574 & .103 & -.275 & .146 & -.626 & 30 & .536 \\
\hline $\begin{array}{l}\text { Pair } \\
2\end{array}$ & $\begin{array}{l}\text { Student's } \\
\text { Collaboration-Student } \\
\text { 's Collaboration } 1\end{array}$ & -.11516 & .64995 & .11673 & -.35356 & .12324 & -.987 & 30 & .332 \\
\hline $\begin{array}{l}\text { Pair } \\
3\end{array}$ & $\begin{array}{l}\text { Student's Cooperation } \\
\text { - Student's } \\
\text { Cooperation } 1\end{array}$ & -.08839 & .79274 & .14238 & -.37917 & .20239 & -.621 & 30 & .539 \\
\hline $\begin{array}{l}\text { Pair } \\
4\end{array}$ & $\begin{array}{l}\text { Teacher's Support - } \\
\text { Teacher's Support } 1\end{array}$ & -.19548 & .64283 & .11546 & -.43127 & .04031 & -1.693 & 30 & .101 \\
\hline $\begin{array}{l}\text { Pair } \\
5\end{array}$ & $\begin{array}{l}\text { Teacher's Leading - } \\
\text { Teacher's Leading } 1\end{array}$ & -.11774 & .70769 & .12711 & -.37733 & .14184 & -.926 & 30 & .362 \\
\hline $\begin{array}{l}\text { Pair } \\
6\end{array}$ & $\begin{array}{l}\text { Classroom } \\
\text { Involvement } \\
\text {-Classroom } \\
\text { Involvement } 1\end{array}$ & -.13710 & .65167 & .11704 & -.37613 & .10194 & -1.171 & 30 & .251 \\
\hline $\begin{array}{l}\text { Pair } \\
7\end{array}$ & $\begin{array}{l}\text { Student's } \\
\text { Responsibility } \\
\text {-Student's } \\
\text { Responsibility 1 }\end{array}$ & .08839 & .75172 & .13501 & -.18735 & .36412 & .655 & 30 & .518 \\
\hline $\begin{array}{l}\text { Pair } \\
8\end{array}$ & $\begin{array}{l}\text { Task Orientation - } \\
\text { Task Orientation } 1\end{array}$ & -.1677 & .6057 & .1088 & -.3899 & .0544 & -1.542 & 30 & .134 \\
\hline $\begin{array}{l}\text { Pair } \\
9\end{array}$ & Equality - Equality 1 & -.27710 & .60092 & .10793 & -.49751 & -.0568 & -2.567 & 30 & .015 \\
\hline $\begin{array}{l}\text { Pair } \\
10\end{array}$ & $\begin{array}{l}\text { Teacher's Innovation } \\
\text { Teacher's Innovation } \\
1\end{array}$ & -.4258 & .9560 & .1717 & -.7765 & -.0751 & -2.480 & 30 & .019 \\
\hline $\begin{array}{l}\text { Pair } \\
11\end{array}$ & $\begin{array}{l}\text { Personality } \\
\text { Characteristics } \\
\text {-Personality } \\
\text { Characteristics 1 }\end{array}$ & -.3490 & .5372 & .0965 & -.5461 & -.1520 & -3.618 & 30 & .001 \\
\hline $\begin{array}{l}\text { Pair } \\
12\end{array}$ & $\begin{array}{l}\text { Psychological State } \\
\text {-Psychological State } 1\end{array}$ & -.038 & .457 & .082 & -.205 & .130 & -.460 & 30 & .649 \\
\hline $\begin{array}{l}\text { Pair } \\
13\end{array}$ & $\begin{array}{l}\text { Classroom } \\
\text { Psychological } \\
\text { Atmosphere - } \\
\text { Classroom } \\
\text { Psychological } \\
\text { Atmosphere } 1\end{array}$ & -.18548 & .59149 & .10624 & -.40245 & .03148 & -1.746 & 30 & .091 \\
\hline
\end{tabular}


From the point of view of T-score, only the perception differences of "Student's Responsibility" $(\mathrm{t}=0.655>0.05)$ does not reach significant level, which shows the success of learning lies in one's responsibility but not in teacher's supervision. Students' perceptions of the other factors have significant differences, indicating that the classroom environment has changed significantly with the flipped classroom teaching mode, and the T-score are negative, indicating that classroom environment is improved. On single factor, the significant of "Equality" $(\mathrm{t}=0.015)$, "Teacher's Innovation" ( $\mathrm{t}=0.019)$, "Personality Characteristics" $(\mathrm{t}=0.001)$ are less than 0.05 , which shows that the three factors increase obviously under flipped classroom mode. These changes coincide with some of the characteristics of flipped classroom: the personal freedom of speech, the teacher is no longer the superior saint [20] and personality gets developed.

Table 4 Independent samples t-test of flipped classroom environment

\begin{tabular}{|c|c|c|c|c|c|}
\hline Grades after & & $\mathrm{N}$ & Mean & $\begin{array}{c}\text { Std. } \\
\text { Deviation }\end{array}$ & Mean Std. Error \\
\hline \multirow{2}{*}{$\begin{array}{l}\text { Student's } \\
\text { Collaboration }\end{array}$} & high & 12 & 4.2100 & .58763 & .16963 \\
\hline & low & 19 & 4.2263 & .48682 & .11168 \\
\hline \multirow[t]{2}{*}{ Student's Cooperation } & high & 12 & 4.1558 & .53335 & .15397 \\
\hline & low & 19 & 4.0232 & .34105 & .07824 \\
\hline \multirow[t]{2}{*}{ Teacher's Support } & high & 12 & 3.722 & .4923 & .1421 \\
\hline & low & 19 & 3.798 & .4103 & .0941 \\
\hline \multirow[t]{2}{*}{ Teacher's Leading } & high & 12 & 3.8558 & .52481 & .15150 \\
\hline & low & 19 & 3.8479 & .36304 & .08329 \\
\hline \multirow{2}{*}{$\begin{array}{l}\text { Classroom } \\
\text { Involvement }\end{array}$} & high & 12 & 3.6892 & .50233 & .14501 \\
\hline & low & 19 & 3.6016 & .19291 & .04426 \\
\hline \multirow{2}{*}{$\begin{array}{l}\text { Student's } \\
\text { Responsibility }\end{array}$} & high & 12 & 3.7025 & .64642 & .18660 \\
\hline & low & 19 & 3.7589 & .30146 & .06916 \\
\hline \multirow[t]{2}{*}{ Task Orientation } & high & 12 & 3.875 & .4957 & .1431 \\
\hline & low & 19 & 3.889 & .3430 & .0787 \\
\hline \multirow[t]{2}{*}{ Equality } & high & 12 & 4.1792 & .46839 & .13521 \\
\hline & low & 19 & 4.0895 & .42883 & .09838 \\
\hline \multirow[t]{2}{*}{ Teacher's Innovation } & high & 12 & 4.000 & .6267 & .1809 \\
\hline & low & 19 & 4.053 & .4312 & .0989 \\
\hline \multirow{2}{*}{$\begin{array}{l}\text { Personality } \\
\text { Characteristics }\end{array}$} & high & 12 & 3.683 & .4130 & .1192 \\
\hline & low & 19 & 3.716 & .4337 & .0995 \\
\hline \multirow[t]{2}{*}{ Psychological State } & high & 12 & 3.61 & .364 & .105 \\
\hline & low & 19 & 3.54 & .400 & .092 \\
\hline Classroom & high & 12 & 3.8333 & .35887 & .10360 \\
\hline Atmosphere & low & 19 & 3.8026 & .35919 & .08240 \\
\hline
\end{tabular}


Perception Differences of Students of Different Levels on Flipped Classroom Environment. The students are divided into two groups according to their scores, lower than 80 is "low", 80 and above is "high". The following table 4 and table 5 are obtained by independent sample t-test,

From the mean, students' perceptions of "Student's Collaboration", "Student's cooperation", "Equality" and "Teacher's Innovation" are more than 4 points, indicating the students are satisfied with the classroom environment of flipped classroom. From the standard deviation, psychological environment perception of high-score students compared to low-score students' is of greater differences, and classroom social environment perception of low-score students is of less differences, which confirm high-score students have a better sensitivity to the changes of classroom environment. On "Student's Cooperation", "Teacher's Leading", "Classroom Involvement", "Student's Responsibility", "Task Orientation" and "Teacher's Innovation", perception differences of the high-score students are significantly higher than that of low-score, which reflect the interaction of innovation traits, what the traditional Reading, Writing and Translating classroom are lack of. Meanwhile, students of high-score think that cooperation, active participation in the classroom, responsible for their own learning, correct task orientation and teacher's active leadership and innovation are important factors in successful language learning.

Through the 2-tailed test, although several perception differences of the factors of high and low proficiency students do not reach significant level, but from the T-score, the differences are existing. Low-score students' perceptions on "Student's cooperation", "Teacher's Leading", "Classroom Involvement", "Equality", "Psychological State "and "Classroom Psychological Atmosphere" are higher than that of high-score students, which illustrate under the flipped classroom, the low score students' awareness of cooperation, orientation to the classroom and teacher's role have improved to some extent. Generally, flipped classroom teaching mode has improved the classroom environment. Students have a certain perception differences, and the high-score group is more sensitive than that of the low-score group. From the results, the grades of low-score students have been improved, so whether there are environmental perception differences between non-flipped and flipped classroom among students of low-score or not is worth exploring.

Low-Score Students' Perceptions of Non-flipped Classroom (NFC) and Flipped Classroom (FC) Environment. We take the pre-test and post-test data of students with scores lower than 70 points to do paired sample t-test, factors notation are the same as Table 3, and table 6 is obtained,

The low level students" "Student's Cooperation"( $\mathrm{t}=1.021)$, “Classroom Involvement" $(\mathrm{t}=0.764)$, "Student's Responsibility" $(\mathrm{t}=0.290)$, "Psychological State" $(\mathrm{t}=1.206)$, whose $\mathrm{t}$-score are greater than 0.05 , which shows that there is no significant difference than before, which maybe because the language foundation of them is weak and the classroom psychological stress making them do not know how to communicate with peers, how to take the initiative to participate in class discussions, and they cannot fully understand that the success or failure learning are all of their own main responsibility. And the perceptions of other factors have a certain difference, but the difference is not particularly significant, which has some relationship with our single simple sample.

Interview Analyses. Through interviews with several students of different levels, the flipped classroom environment is further understood. Student A thinks the tasks the teacher assigns before class sometimes are cumbrous, which are difficult to be completely absorbed before next class, and he unconsciously spends more time in Reading, Writing and Translating course, though does not adapt fully, the grades are improved. Student B believes that the communication of students and teachers in classroom has increased so as to the classroom atmosphere becomes very harmonious. And the mid-term test and final exam are combined to evaluate their performance, which reduces the face tension in the final exam, so she hopes to continue such assessments next semester. According to Student $\mathrm{C}$, he has much more opportunities to speak freely in class. He like the section of reviewing writing and translation works for each other most. Like she says, "We don't get bogged down in the form, become freer to participate in the mission, and become more intimate than the original period." In short, students of different levels have different feelings and perceptions to the flipped classroom teaching mode, the majority of students have benefited greatly. 
Some gets performance improved, some gets interpersonal relationship consolidated, and some gains personality developed.

Table 5 Independent sample t-test for factors of flipped classroom environment

\begin{tabular}{|c|c|c|c|c|c|c|c|c|}
\hline & & \multicolumn{7}{|c|}{ T-test for Equality of Means } \\
\hline & & \multirow[b]{2}{*}{$\mathrm{t}$} & \multirow[b]{2}{*}{ df } & \multirow{2}{*}{$\begin{array}{l}\text { Sig. } \\
\text { (2-tailed } \\
\text { ) }\end{array}$} & \multirow{2}{*}{$\begin{array}{c}\text { Mean } \\
\text { Differen } \\
\text { ce }\end{array}$} & \multirow{2}{*}{$\begin{array}{l}\text { Std. Error } \\
\text { Differenc } \\
\mathrm{e}\end{array}$} & \multicolumn{2}{|c|}{$\begin{array}{l}95 \% \quad \text { Confidence } \\
\text { interval } \\
\text { of the Difference }\end{array}$} \\
\hline & & & & & & & $\begin{array}{c}\text { Lower } \\
\text { Limited }\end{array}$ & $\begin{array}{l}\text { Upper } \\
\text { Limited }\end{array}$ \\
\hline $\begin{array}{l}\text { Student's } \\
\text { Collaboratio }\end{array}$ & $\begin{array}{c}\text { Equal variances } \\
\text { assumed }\end{array}$ & -.084 & 29 & .934 & -.01632 & .19444 & -.41400 & .38137 \\
\hline $\mathrm{n}$ & $\begin{array}{l}\text { Equal } \\
\text { variances not } \\
\text { assumed }\end{array}$ & -.080 & 20.275 & .937 & -.01632 & .20310 & -.43960 & .40697 \\
\hline \multirow[t]{2}{*}{$\begin{array}{l}\text { Student's } \\
\text { Cooperation }\end{array}$} & $\begin{array}{l}\text { Equal variances } \\
\text { assumed }\end{array}$ & .848 & 29 & .403 & .13268 & .15648 & -.18736 & .45272 \\
\hline & $\begin{array}{l}\text { Equal } \\
\text { variances not } \\
\text { assumed }\end{array}$ & .768 & 16.733 & .453 & .13268 & .17270 & -.23214 & .49749 \\
\hline \multirow[t]{2}{*}{$\begin{array}{l}\text { Teacher's } \\
\text { Support }\end{array}$} & $\begin{array}{c}\text { Equal variances } \\
\text { assumed }\end{array}$ & -.470 & 29 & .642 & -.0768 & .1634 & -.4110 & .2575 \\
\hline & $\begin{array}{l}\text { Equal } \\
\text { variances not } \\
\text { assumed }\end{array}$ & -.450 & 20.371 & .657 & -.0768 & .1705 & -.4319 & .2784 \\
\hline \multirow[t]{2}{*}{$\begin{array}{l}\text { Teacher's } \\
\text { Leading }\end{array}$} & $\begin{array}{c}\text { Equal variances } \\
\text { assumed }\end{array}$ & .050 & 29 & .961 & .00794 & .15914 & -.31755 & .33343 \\
\hline & $\begin{array}{l}\text { Equal } \\
\text { variances not } \\
\text { assumed }\end{array}$ & .046 & 17.667 & .964 & .00794 & .17288 & -.35577 & .37164 \\
\hline \multirow[t]{2}{*}{$\begin{array}{l}\text { Classroom } \\
\text { Involvement }\end{array}$} & $\begin{array}{l}\text { Equal variances } \\
\text { assumed }\end{array}$ & .689 & 29 & .496 & .08759 & .12710 & -.17236 & .34754 \\
\hline & $\begin{array}{l}\text { Equal } \\
\text { variances not } \\
\text { assumed }\end{array}$ & .578 & 13.075 & .573 & .08759 & .15161 & -.23976 & .41494 \\
\hline $\begin{array}{l}\text { Student's } \\
\text { Responsibili }\end{array}$ & $\begin{array}{l}\text { Equal variances } \\
\text { assumed }\end{array}$ & -.330 & 29 & .744 & -.05645 & .17094 & -.40605 & .29316 \\
\hline ty & $\begin{array}{l}\text { Equal } \\
\text { variances not } \\
\text { assumed }\end{array}$ & -.284 & 14.067 & .781 & -.05645 & 19901 & -.48309 & .37019 \\
\hline \multirow[t]{2}{*}{$\begin{array}{l}\text { Task } \\
\text { Orientation }\end{array}$} & $\begin{array}{l}\text { Equal variances } \\
\text { assumed }\end{array}$ & -.096 & 29 & .924 & -.0145 & .1503 & -.3219 & .2930 \\
\hline & $\begin{array}{l}\text { Equal } \\
\text { variances not } \\
\text { assumed }\end{array}$ & -.089 & 17.673 & .930 & -.0145 & .1633 & -.3580 & .3291 \\
\hline \multirow[t]{2}{*}{ Equality } & $\begin{array}{l}\text { Equal variances } \\
\text { assumed }\end{array}$ & .548 & 29 & .588 & .08969 & .16381 & -.24534 & .42472 \\
\hline & $\begin{array}{l}\text { Equal } \\
\text { variances not } \\
\text { assumed }\end{array}$ & .536 & 21.967 & .597 & 08969 & .16722 & -.25712 & .43651 \\
\hline \multirow[t]{2}{*}{$\begin{array}{l}\text { Teacher's } \\
\text { Innovation }\end{array}$} & $\begin{array}{c}\text { Equal variances } \\
\text { assumed }\end{array}$ & -.278 & 29 & .783 & -.0526 & . 1896 & -.4404 & .3351 \\
\hline & $\begin{array}{l}\text { Equal } \\
\text { variances not } \\
\text { assumed }\end{array}$ & -.255 & 17.601 & .801 & -.0526 & .2062 & -.4865 & .3813 \\
\hline $\begin{array}{l}\text { Personality } \\
\text { Characteristi }\end{array}$ & $\begin{array}{l}\text { Equal variances } \\
\text { assumed }\end{array}$ & -.207 & 29 & .838 & -.0325 & .1571 & -.3537 & .2888 \\
\hline
\end{tabular}


Table 5,cont.

\begin{tabular}{|ll|r|r|r|r|r|r|r|}
\hline cs & $\begin{array}{l}\text { Equal } \\
\text { variances not } \\
\text { assumed }\end{array}$ & -.209 & 24.416 & .836 & -.0325 & .1553 & -.3527 & .2878 \\
$\begin{array}{l}\text { Psychologic } \\
\text { al State }\end{array}$ & $\begin{array}{l}\text { Equal variances } \\
\text { assumed } \\
\text { Equal } \\
\text { variances not } \\
\text { assumed }\end{array}$ & .473 & 29 & .640 & .067 & .143 & -.224 & .359 \\
$\begin{array}{l}\text { Equal variances } \\
\text { assumed } \\
\text { Classroom }\end{array}$ & .232 & 25.202 & .633 & .067 & .140 & -.220 & .355 \\
$\begin{array}{l}\text { Psychologic } \\
\text { Atmosphere }\end{array}$ & $\begin{array}{l}\text { Equal } \\
\text { variances not } \\
\text { assumed }\end{array}$ & .232 & 23.560 & .819 & .03070 & .13237 & -.24278 & .30418 \\
\hline
\end{tabular}

Table 6 Paired samples t-test for low points group of NFC and FC

\begin{tabular}{|c|c|c|c|c|c|c|c|c|c|}
\hline & & \multicolumn{5}{|c|}{ Paired Samples t-test } & \multirow[b]{3}{*}{$\mathrm{t}$} & \multirow[b]{3}{*}{$\mathrm{df}$} & \multirow{3}{*}{$\begin{array}{l}\text { Sig. } \\
\text { (2-tail } \\
\text { ed) }\end{array}$} \\
\hline & & \multirow[b]{2}{*}{ Mean } & \multirow[b]{2}{*}{$\begin{array}{c}\text { Std. } \\
\text { Deviation }\end{array}$} & \multirow{2}{*}{$\begin{array}{l}\text { Mean } \\
\text { Std. } \\
\text { Error }\end{array}$} & \multicolumn{2}{|c|}{$\begin{array}{l}\text { 95\% Confidence } \\
\text { interval of the } \\
\text { Difference }\end{array}$} & & & \\
\hline & & & & & $\begin{array}{c}\text { Lower } \\
\text { Limited }\end{array}$ & $\begin{array}{c}\text { Upper } \\
\text { Limited } \\
\end{array}$ & & & \\
\hline $\begin{array}{l}\text { Pair } \\
1\end{array}$ & $\begin{array}{l}\text { Grades } \\
\text { before-Grades } \\
\text { after }\end{array}$ & -.400 & .548 & .245 & -1.080 & .280 & -1.633 & 4 & .178 \\
\hline $\begin{array}{l}\text { Pair } \\
2\end{array}$ & $\begin{array}{l}\text { Student's } \\
\text { Collaboration-St } \\
\text { udent's } \\
\text { Collaboration } 1\end{array}$ & .22300 & .48850 & .21846 & -.38355 & .82955 & 1.021 & 4 & .365 \\
\hline $\begin{array}{l}\text { Pair } \\
3\end{array}$ & $\begin{array}{l}\text { Student's } \\
\text { Cooperation - } \\
\text { Student's } \\
\text { Cooperation } 1\end{array}$ & -.08600 & .96968 & .43365 & -1.29002 & 1.11802 & -.198 & 4 & .852 \\
\hline $\begin{array}{l}\text { Pair } \\
4\end{array}$ & $\begin{array}{l}\text { Teacher's } \\
\text { Support - } \\
\text { Teacher's } \\
\text { Support } 1\end{array}$ & -.40000 & .71053 & .31776 & -1.28224 & .48224 & -1.259 & 4 & .277 \\
\hline $\begin{array}{l}\text { Pair } \\
5\end{array}$ & $\begin{array}{l}\text { Teacher's } \\
\text { Leading - } \\
\text { Teacher's } \\
\text { Leading } 1\end{array}$ & -.27200 & 1.32924 & .59445 & -1.92247 & 1.37847 & -.458 & 4 & .671 \\
\hline $\begin{array}{l}\text { Pair } \\
6\end{array}$ & $\begin{array}{l}\text { Classroom } \\
\text { Involvement } \\
\text {-Classroom } \\
\text { Involvement } 1\end{array}$ & .27400 & .80180 & .35857 & -.72156 & 1.26956 & .764 & 4 & .487 \\
\hline $\begin{array}{l}\text { Pair } \\
7\end{array}$ & $\begin{array}{l}\text { Student's } \\
\text { Responsibility } \\
\text {-Student's } \\
\text { Responsibility } 1\end{array}$ & .14400 & 1.11145 & .49706 & -1.23605 & 1.52405 & .290 & 4 & .786 \\
\hline $\begin{array}{l}\text { Pair } \\
8\end{array}$ & $\begin{array}{l}\text { Task Orientation } \\
\text { - Task } \\
\text { Orientation } 1\end{array}$ & -.3600 & .8989 & .4020 & -1.4761 & .7561 & -.896 & 4 & .421 \\
\hline $\begin{array}{l}\text { Pair } \\
9\end{array}$ & $\begin{array}{l}\text { Equality - } \\
\text { Equality } 1\end{array}$ & -.22800 & .62347 & .27883 & -1.00215 & .54615 & -.818 & 4 & .459 \\
\hline $\begin{array}{l}\text { Pair } \\
10\end{array}$ & $\begin{array}{l}\text { Teacher's } \\
\text { Innovation } \\
\text { Teacher's }\end{array}$ & -.4000 & 1.2884 & .5762 & -1.9998 & 1.1998 & -.694 & 4 & .526 \\
\hline
\end{tabular}


Table 6, cont.

\begin{tabular}{|c|c|c|c|c|c|c|c|c|c|}
\hline & Innovation 1 & & & & & & & & \\
\hline $\begin{array}{l}\text { Pair } \\
11\end{array}$ & $\begin{array}{l}\text { Personality } \\
\text { Characteristics } \\
\text {-Personality } \\
\text { Characteristics 1 }\end{array}$ & -.04200 & .54947 & .24573 & -.72426 & .64026 & -.171 & 4 & .873 \\
\hline $\begin{array}{l}\text { Pair } \\
12\end{array}$ & $\begin{array}{l}\text { Psychological } \\
\text { State } \\
\text {-Psychological } \\
\text { State 1 }\end{array}$ & .13400 & .24846 & .11111 & -.17450 & .44250 & 1.206 & 4 & .294 \\
\hline $\begin{array}{l}\text { Pair } \\
13\end{array}$ & $\begin{array}{l}\text { Classroom } \\
\text { Psychological } \\
\text { Atmosphere - } \\
\text { Classroom } \\
\text { Psychological } \\
\text { Atmosphere 1 }\end{array}$ & -.05000 & 67082 & .30000 & -.88293 & .78293 & -.167 & 4 & .876 \\
\hline
\end{tabular}

\section{Discussion}

The statistical analysis of quantitative data shows that students are more satisfied with Reading, Writing and Translating flipped classroom environment than before, but students' perceptions of factors of classroom environment are of difference. Combining with the qualitative data of the interview and classroom observation, we try to discuss the implementation characteristics of flipped classroom in Reading, Writing and Translating from the perspective of classroom environment, and put forward some suggestions for improving the teaching quality.

1. Autonomy learning of "Scrambled in appearance but united in spirit"

"Mass but not scrambled", "order active" is a high effective classroom orientation and pursuit [21]. In the flipped classroom, students can freely ask questions, take the initiative to speak and act more actively, sometimes class seems to be "scattered", but classroom order can still maintain good. Everyone asks or offers help to classmates or interacts with teachers according to their master degree, and when encountering new problems and new discoveries, they will be happy to share with each other. Such a classroom appears to be "chaos" on the surface, but "chaos of order". Classroom seems to be "of mass", but the actual teaching and learning becomes more effective. Students become "the active pursuer" of learning, which is the "soul" of successful classroom. Flipped classroom teaching mode helps to achieve the students' autonomy learning of "Scrambled in appearance but united in spirit". But it requires the teacher appropriate degree of leading and controlling the classroom teaching, taking students as the center, making dialogue and exchange with students as the basic standard, such teacher will produce a positive effect to the autonomy learning of students.[22]

2. Highlight the "students based, teachers supplemented" cooperative learning

Flipped classroom teaching mode can optimize the classroom environment of Reading, Writing and Translating class. It takes the advantages of the multimedia technology handing out the learning tasks in advance, students can complete learning tasks out of class so that the students can be guaranteed to get enough time to explore the effective reading skills and writing strategies in class and classroom contents are targeted while classroom activities are diversified. The organization and leading role of the teacher in classroom makes the teacher become the director instead of the main performer of the classroom [23], and the student's central position can be established. How to balance the position of teacher and students in classroom teaching is a key consideration in flipped classroom teaching mode.

3. Construct mutual assistance classroom learning atmosphere

The study shows that there are significant differences between students in the classroom environment of Reading, Writing and Translating, and the high level students are more sensitive to the changes of classroom environment than that of the low level students. Perception differences of 
Reading, Writing and Translating classroom environment of students of different levels show in the participation degree, cooperation and mutual assistance degree and personality traits, that is to say, students' perception of classroom environment is of personalized features. Because of the course characteristics, students maintain a long time passive receiving state in class, but students' satisfaction has increased overall in flipped classroom, especially to participation in classroom interaction and cooperative learning atmosphere. Successful teaching and learning should be common responsibility process of construction of cooperative interaction and relaxed learning atmosphere so as to achieve highly effective integration, which is commonly led by the teacher and cooperated by the students.

4. Diversity and individual comprehensive development

Based on the differences of students' perception of classroom environment, especially the low level learners, to their performance and psychology in the classroom should be paid more attention. In the process of teaching, enriching classroom activities, diversifying in form and considering the personality development of students is a way forward. The advantages of the flipped classroom lie in that students master the knowledge integration initiatively; each learner has the unique approach. In class, the teacher and the students have enough time to discuss multi-angle reading, writing and translating strategies, so the students can take advantages of others to make up their own weaknesses. Not only single benchmark but a better model is one of the characteristics of reading and writing classroom. On the basis of grasping subject knowledge, students' communication ability, cooperation ability, critical thinking ability, practical ability and emotional experience can better be excited in the flipped classroom, which is ultimate goal that teaching and learning should achieve.

\section{Conclusion}

It is an important way to promote effective teaching and improve the quality of classroom teaching from the perspective of students' perception of classroom environment. The role of classroom environment in language teaching is of significance. This study discusses the characteristics of the classroom environment of College English Reading, Writing and Translating under flipped classroom teaching mode, and puts forward some suggestions on the effective teaching of Reading, Writing and Translating class. The research has some limitations, it is that the sample is single, and the teaching experiment time is not long enough, which has certain impact on the research results. Future research can expand the sample to explore the relationship between environment refined factors and the learners' self-efficacy, the relationship between classroom environment and learning motivation and so on to construct efficient Reading, Writing and Translating classroom environment theory model.

\section{Acknowledgements}

Teaching research project of Hubei Provincial Department of Education: "College English Reading, Writing and Translating Classroom Environment Research" (No. 2012230)

Humanities and social science teaching research project of Hubei Provincial Department of Education: Exploration on the Reform of College English Teaching from the Perspective of "Higher Education in Hubei Province Metallurgy Innovative Talents Cultivation Plan" (No. 13g148)

\section{References}

[1] J.G. CAI: Foreign Language World, (2011) No.1, p.21-29. (In Chinese)

[2] S. L. Yu, J. Y. Han and J.J. Wang: Foreign Language World, (2012) No.1, p.28-34. (In Chinese)

[3] Q.H. Zhao and J.F. Xu: Foreign Language World, (2011) No.1, p.30-37. (In Chinese)

[4] B. J. Fraser: Classroom Environment (Routledge, New York 2012). p.1.

[5] C.L. Fan and Q. Dong: Comparative Education Review, Vol.183 (2005) No.8, p.61-66. (In 


\section{Chinese)}

[6] H. Y. Sun: Education Science, Vol.26 (2010) No.3. (In Chinese)

[7] Y. M. Sun: Foreign Language Teaching and Research, Vol. 42(2010) No. 6, p. 438-444. (In Chinese)

[8] Z. Gao: Shandong Foreign Language Teaching Journal, Vol.135 (2010) No.2. (In Chinese)

[9] L.Y. Liu, Y. P. Ma and Y. B. Liu: Studies in Foreign Education, Vol.36 (2009) No.5. (In Chinese)

[10]Q. M. Ren: Foreign Language Teaching and Research, Vol.45 (2013) No.5. (In Chinese)

[11]D.W. Han and Q. Deng: CAFLE, (2014) No.158, p.44-50. (In Chinese)

[12]G. F. Li and F. F. Guo; Foreign Languages and Their Teaching, Vol.280 (2015) No.1. (In Chinese)

[13]Quek C. L and Wong A. F. L. Teaching and Learning, Vol.23 (2002) No.2, p.107-118.

[14]Y.M. Sun: The Study on Chinese Learners' Sociopsychological Environment in the Foreign Language Classrooms (Ph.D., Huazhong University of Science and Technology, China 2007). (In Chinese)

[15]J. Bergmann and A. Sams: Flipping the Classroom (Tech \&Learning, San Bruno 2012), p.42-43.

[16]J. L. Zhang, Y. Wang and B.H. Zhang: Journal of Distance Education, (2012) No.4, p.46-51. (In Chinese)

[17]J. L. Zhang: Distance Education in China, (2013) p.59-64. (In Chinese)

[18]H. Y. L u: CAFLE, (2014) No.158, p.33-36. (In Chinese)

[19]Z.Y. He: Higher Engineering Education Research, (2014) No.2, p.150. (In Chinese)

[20]H. J. Wang and L. Zhang: Teaching and Management, (2014) p.141. (In Chinese)

[21]A. L. Tian and Z. H. Wu: Journal of Chinese Education, (2014) p.32. (In Chinese)

[22]P. Benson: Teaching and Researching: Autonomy in Language Learning (Routledge, New York 2013)

[23]T. Z. Yu: Teacher Education, (2014) p.49-67. (In Chinese) 